\title{
PENGARUH PERHATIAN ORANG TUA DAN KEHARMONISAN \\ KELUARGA TERHADAP MOTIVASI BELAJAR SISWA KELAS VIII SMP NEGERI 1 KEBONSARI KABUPATEN MADIUN
}

\author{
Ika Novitasari Fitrianingrum * \\ Kardi **
}

\begin{abstract}
Abstrak
Tujuan penelitian adalah untuk mengetahui "Pengaruh perhatian orang tua dan keharmonisan keluarga terhadap motivasi belajar siswa kelas VIII SMP Negeri 1 Kebonsari Kabupaten Madiun.

Sampel penelitian ditetapkan sebanyak 40 orang siswa dari 166 siswa anggota populasi. Penetapan anggota sampel menggunakan teknik random sampling. Pengumpulan data penelitian menggunakan teknik angket. Teknik angket untuk memperoleh data tentang perhatian orang tua, keharmonisan keluarga, dan motivasi belajar.

Analisis data penelitian tentang (1) pengaruh $\mathrm{X}_{1}$ terhadap $\mathrm{Y}$; dan (2) pengaruh $\mathrm{X}_{2}$ terhadap $\mathrm{Y}$ dianalisis dengan korelasi Product Moment. Analisis data tentang pengaruh $\mathrm{X}_{1}$ dan $\mathrm{X}_{2}$ terhadap $\mathrm{Y}$ dengan Analisis Regresi: Dua Prediktor. Hasil analisis data menunjukkan bahwa: (a) $\mathrm{rx}_{1} \mathrm{y}$ lebih besar dibandingkan harga $\mathrm{r}$-tabel $(0,481>0,316 / \mathrm{TS}=5 \%)$, berarti signifikan. (b) $\mathrm{rx}_{2} \mathrm{y}$ lebih besar dibanding harga $\mathrm{r}-$ tabel $(0,858>0,325 / \mathrm{TS}=5 \%)$, berarti signifikan. Hasil F-regresi $=74.5 \mathrm{t} 2$. Harga F-tabel dengan 2 lawan 37 adalah 3,25/TS=5\%. Jadi harga F-reg > harga F-tabel (sangat signifikan/TS=5\%).

Simpulan penelitian: (a) Ada pengaruh perhatian orang tua terhadap motivasi belajar siswa kelas VIII SMP Negeri 1 Kebonsari Kabupaten Madiun; (b) Ada pengaruh keharmonisan keluarga terhadap motivasi belajar siswa kelas VIII SMP Negeri 1 Kebonsari Kabupaten Madiun; (c) Ada pengaruh perhatian orang tua dan keharmonisan keluarga terhadap motivasi belajar siswa kelas VIII SMP Negeri 1 Kebonsari Kabupaten Madiun. Saran: sekolah bekerja sama dengan pihak orang tua untuk selalu memelihara perhatian, keharmonisan antar siswa dan staf sekolah, sehingga membantu motivasi belajar siswa di sekolah.
\end{abstract}

\section{Kata kunci : Perhatian Orang Tua, Keharmonisan Keluarga, Motivasi Belajar}

\footnotetext{
* Ika Novitasari Fitrianingrum adalah Mahasiswa Program Studi Bimbingan dan Konseling Fakultas Ilmu Pendidikan IKIP PGRI Madiun.

** Kardi adalah Dosen Program Studi Bimbingan dan Konseling Fakultas Ilmu Pendidikan IKIP PGRI Madiun.
} 


\section{Pendahuluan}

Motivasi belajar siswa di sekolah pada dasarnya merupakan dorongan dari dalam diri siswa, yang perwujudannya dapat dipengaruhi oleh faktor: fisik, psikis dan sosial. Ketiga faktor tersebut dalam kehidupan sehari-hari pelaksanaannya adalah saling melengkapi, dan saling mendukung.

Faktor fisik yang diperkirakan dapat mempengaruhi motivasi belajar siswa di sekolah adalah berkaitan erat dengan kesehatan tubuh. Maksud dari pernyataan ini adalah apabila dalam mewujudkan motivasi belajar didukung oleh kesehatan jasmani yang prima, maka dapat memperlancar tercapainya tujuan yang dikehendaki. Sebaliknya, apabila dalam mewujudkan motivasi belajar ternyata kurang atau bahkan tidak didukung oleh keadaan kesehatan yang prima, maka besar kemungkinannya akan menghambat tercapainya tujuan yang dikehendaki siswa tersebut.

Faktor psikis adalah faktor kejiwaan yang melekat dalam diri siswa. Winkel (dalam Vitalis, 2002: 123) membedakan faktor psikis menjadi dua faktor, yaitu yang bersifat intelektual dan bersifat non-intelektual. Faktor psikis yang bersifat intelektual antara lain meliputi: taraf inteligensi, cara belajar, dan kemampuan belajar. Faktor psikis yang bersifat non-intelektual antara lain berkaitan dengan perhatian dan motivasi belajar siswa. Perhatian diartikan sebagai banyaksedikitnya kesadaran yang menyertai seseorang (siswa) untuk melakukan aktivitas tertentu. Perhatian dalam belajar sangat berpengaruh dalam membantu kelancaran aktivitas belajar, baik di sekolah maupun di luar sekolah. Motivasi belajar secara umum diartikan sebagai daya dorong yang menimbulkan aktivitas pada diri siswa, sehingga tujuan belajar tercapai. Pernyataan tersebut memberi petunjuk bahwa motivasi belajar merupakan faktor yang perlu diperhitungkan ketika seseorang melakukan kegiatan belajar. Pernyataan di atas dapat pula dipahami sebagai semakin besar motivasi dalam belajar, maka semakin banyak membutuhkan energi. Oleh karena itu faktor fisik sangat diperlukan karena akan menambah energi atau daya yang bermanfaat dalam mewujudkan motivasi dalam belajar.

Faktor sosial adalah unsur-unsur yang berkaitan dengan kehadiran orang lain yang terdapat di lingkungan sekitar. Kehadiran orang lain di lingkungan 
sekitar antara lain behubungan dengan orang tua dan keharmonisan keluarga di rumah. Kehadiran orang tua ketika seseorang (anak) melakukan kegiatan belajar, terutama dalam memberi perhatian, maka akan membantu kelancaran dalam mencapai tujuan belajar. Di sisi lain kegiatan belajar perlu didukung oleh keharmonisan keluarga. Apabila kedua faktor tersebut di atas dirasakan oleh siswa ketika melakukan kegiatan belajar, maka dapat menimbulkan semangat siswa dalam belajar, baik di sekolah maupun di luar sekolah. Sebaliknya apabila kedua faktor tersebut tidak saling mendukung, maka kiranya sulit diharapkan dapat memperlancar kegiatan belajar siswa, baik di sekolah maupun di luar sekolah.

Bertolak dari uraian pada latar belakang masalah tersebut di atas maka peneliti merasa tertarik untuk mengadakan penelitian lebih mendalam, sehingga diperoleh kebenaran. Oleh karena itu agar tujuan penelitian lebih terarah, maka masalah penelitian ini dirumuskan sebagai berikut: "Pengaruh Perhatian Orang Tua dan Keharmonisan Keluarga Terhadap Motivasi Belajar Siswa Kelas VIII SMP Negeri 1 Kebonsari Kabupaten Madiun”.

\section{Metode}

\section{A. Metode Penelitian}

Metode penelitian menggunakan deskriptif korelasional ex-post-facto. Donald Ary (dalam Ibadullan Malawi, 2007: 23) menyatakan bahwa metode ex-post-facto adalah "suatu cara penelitian ilmiah yang menuntut peneliti tidak dapat memanipulasi secara langsung variabel bebas". Menurut Sugiyono (2009: 49) alasan lain digunakan merode ex-post-facto adalah peneliti tidak lagi menyusun alat yang spesifik untuk mengungkap data tentang responden, karena data tersebut secara psikologis telah melekat pada diri rensponden (siswa). Berdasarkan dua pendapat di atas, maka penggunaan metode ex-post-facto dalam penelitian ini telah dapat dipertanggungjawabkan secara metodologis. 


\section{B. Desain Penelitian}

Desain penelitian ini menggunakan rancangan deskriptif korelas expost-facto. Desain penelitian tersebut dilaporkan dalam bentuk bagan seperti dapat dilihat pada bagan 1 di bawah .

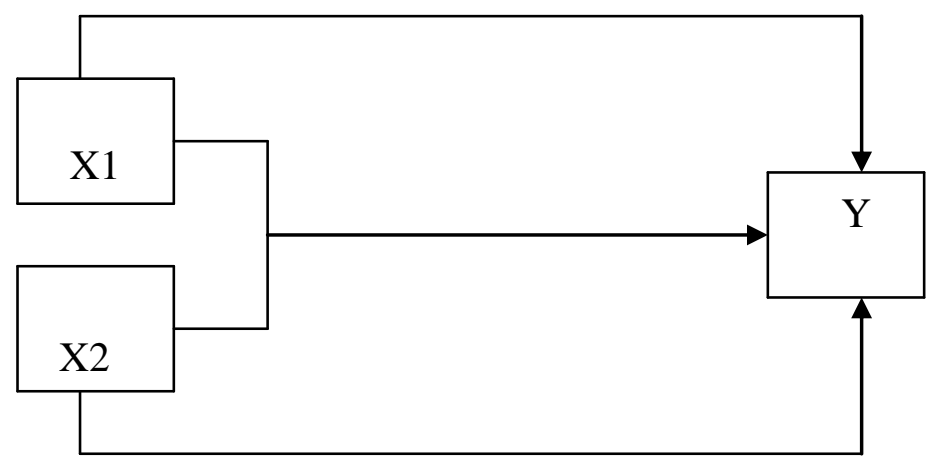

Gambar 1. Desain Deskriptif Korelaional Ex-post-facto

\section{Keterangan:}

$\mathrm{X}_{1}$ : Perhatian orang tua

$\mathrm{X}_{2}$ : Keharmonisan keluarga

Y : Motivasi belajar

\section{Populasi Dan Sampel Penelitian}

1. Populasi Penelitian

Populasi penelitian adalah siswa kelas VIII SMP Negeri 1 Kebonsari Kabupaten Madiun, dengan jumlah siswa adalah 166 siwa.

2. Sampel Penelitian

Jumlah sampel penelitian ditetapkan sebanyak 40 siswa dari 166 anggota populasi atau sekitar $24,1 \%$.. Hal ini di dukung oleh pendapat Suharsimi Arikunto (2006: 134) jika subjek penelitian dibawah 100 maka lebih baik diambil semua sebagai sampel dan jika subjeknya lebih dari 100 dapat diambil 10-15\%, 20-25\% atau lebih.

Penetapan sampel penelitian menggunakan random sampling. Penggunaan random sampling bertujuan agar tidak adanya diskriminasi dan semua populasi berpeluang menjadi sampel penelitian. Hal tersebut didukung oleh pendapat Sutrisno Hadi (2002: 303 ) yang mengemukakan 
dasar pokok random sampling adalah semua anggota populasi mempunyai peluang sama untuk dimasukkan menjadi anggota sampel.

Randomisasi untuk anggota sampel penelitian ini dilakukan dengan cara sebagai berikut:

a) Membuat daftar seluruh populasi.

b) Menuliskan nomer urut siswa yang menjadi anggota sampel penelitian dari nomor 1-166

c) Menuliskan kode nomer anggota sampel pada selembar kertas kecil dan kemudian digulung rapi.

d) Masukan kertas kecil dalam sebuah gelas yang atasnya tertutup rapat namun diberi lubang kecil untuk mengeluarkan satu gulungan kertas lalu kocok-kocok gulungan kertas didalam gelas tersebut.

e) Mendaftar nomer yang keluar sebagai anggota sampel.

Jadi peneliti mengambil sampel $24,1 \%$ dari populasi tersebut. Dalam penelitian ini mengambil sampel sebanyak 40 siswa dari siswa kelas VIII SMP Negeri 1Kebonsari Kabupaten Madiun.

\section{Teknik Pengumpulan Data}

Tehnik pengumpulan data dalam penelitian ini menggunakan angket. Tehnik angket digunakan untuk memperoleh data tentang perhatian orang tua, keharmonisan keluarga dan motivasi belajar.

Angket dalam penelitian ini disusun sendiri oleh peneliti dalam bentuk pilihan ganda. Angket disusun dalam bentuk langsung dan tertutup. Angket langsung adalah responden menjawab sesuai dengan keadaan dirinya. Angket tertutup adalah angket yang jawabannya sudah disediakan sehingga reponden tinggal memilih sesuai keadaan dirinya. Untuk memudahkan responden dalam menjawab item-item angket disusun dengan empat alternatif jawaban yaitu: a, b, c, d. 
Cara pemberian penilaian hasil angket adalah sebagai berikut:

Tabel 2. Distribusi Skor Untuk Jawaban Angket

\begin{tabular}{|l|c|c|c|c|}
\hline Jawaban & Selalu & Sering & Kadang & $\begin{array}{l}\text { Tidak } \\
\text { pernah }\end{array}$ \\
\hline Skor & 4 & 3 & 2 & 1 \\
\hline
\end{tabular}

Bertolak dari uraian diatas dapat dijabarkan sebagai berikut :

(1) Jika siswa menjawab selalu mendapat skor 4.

(2) Jika siswa menjawab sering mendapat skor 3.

(3) Jika siswa menjawab kadang-kadang mendapat skor 2.

(4) Jika siswa menjawab tidak pernah item mendapat skor 1.

Alasan peneliti menggunakan empat alternatif jawaban yaitu, untuk menghindari jawaban yang memberikan makna ambigu dan untuk menghindari responden yang pasif dan cenderung memilih posisi aman tanpa memberi jawaban yang pasti, karena respon yang kita inginkan adalah respon yang diyakini subjek (dalam Brillian Fajar Septanto, 2011: 28). Jumlah item tiap variabel sebanyak 15 butir.

Untuk memudahkan analisis data dengan statistik, maka variabel perhatian orangtua diberi kode $\left(\mathrm{X}_{1}\right)$, keharmonisan keluarga diberi kode $\left(\mathrm{X}_{2}\right)$, dan motivasi belajar diberi kode (Y).

Item angket disusun atas dasar kisi-kisi yang disusun sebelumnya. Kisi-kisi angket tersebut memuat indikator item angket, Indikator item angket disusun atas dasar unsur-unsur yang terdapat dalam definisi atau pengertian masing-masing variabel penelitian.

Indikator-indikator item angket pada prinsipnya memiliki peran ganda, yaitu (1) memberi arah pada penyusunan item angket, sehingga sesuai dengan unsur-unsur yang terdapat dalam definisi setiap variabel penelitian, dan (2) berkaitan dengan pengujian validitas dan reliabilitas butir item pada instrument (angket) cukup dengan menggunakan validitas logis, dengan validitas isi. 
Pernyataan di atas sesuai dengan pendapat Wayan Nurkancana dan P.P.N. Sumartana (dalam Vitalis 2007: 128) yang menyatakan: "Untuk menilai validitas isi instrument (angket) dilakukan dengan jalan membandingkan materi instrumen yang disediakan dengan analisis rasional yang dilakukan terhadap bahan-bahan yang seharusnya dipergunakan dalam menyusun instrumen (angket) tersebut". Dengan demikian maka item angket dalam penelitian ini tidak perlu diujicobakan apabila ingin menguji validitas dan reliabilitas.

Kisi-kisi angket penelitian tentang perhatian orangtua dapat dilihat pada tabel 3, keharmonisan keluarga pada tabel 4, dan motivasi belajar pada tabel 5 .

Tabel 3. Kisi-kisi Angket Tentang Perhatian Orang Tua

\begin{tabular}{|c|l|c|c|}
\hline No. & \multicolumn{1}{|c|}{ Indikator Item } & $\begin{array}{c}\text { Nomor } \\
\text { Item }\end{array}$ & $\begin{array}{c}\Sigma \\
\text { Item }\end{array}$ \\
\hline 1 & $\begin{array}{l}\text { Kesadaran orang tua dalam memenuhi kebutuhan } \\
\text { fisik anak. }\end{array}$ & $1,2,3$ & 3 \\
\hline 2 & $\begin{array}{l}\text { Kesadaran orang tua dalam memenuhi kebutuhan } \\
\text { psikis anak. }\end{array}$ & $4,5,6,7,8$ & 5 \\
\hline 3 & $\begin{array}{l}\text { Kesadaran orang tua dalam memenuhi fasilitas } \\
\text { belajar anak. }\end{array}$ & $9,10,11,12$ & 4 \\
\hline 4 & $\begin{array}{l}\text { Kesadaran orang tua dalam membantu anak } \\
\text { mencapai cita-cita hidupnya }\end{array}$ & $13,14,15$ & 3 \\
\hline & \multicolumn{1}{|c|}{ Total Pernyataan: } & 15 \\
\hline
\end{tabular}

Tabel 4. Kisi-kisi Angket Tentang Keharmonisan Keluarga

\begin{tabular}{|c|l|c|c|}
\hline No. & \multicolumn{1}{|c|}{ Indikator Item } & $\begin{array}{c}\text { Nomor } \\
\text { Item }\end{array}$ & $\begin{array}{c}\Sigma \\
\text { Item }\end{array}$ \\
\hline 1 & $\begin{array}{l}\text { Keserasian dalam berkomunikasi antara orang tua } \\
\text { dan anak. }\end{array}$ & $1,2,3$ & 3 \\
\hline 2 & $\begin{array}{l}\text { Kesediaan orang tua berdiskusi dengan anak } \\
\text { tentang kegiatan belajar anak. }\end{array}$ & $4,5,67,8$ & 5 \\
\hline 3 & $\begin{array}{l}\text { Pola kepemimpinan yang dikembangkan orang } \\
\text { tua dalam keluarga }\end{array}$ & $9,10,11,12$ & 4 \\
\hline 4 & $\begin{array}{l}\text { Kemampuan orang tua menerapkan pendidikan } \\
\text { kepada anak }\end{array}$ & $13,14,15$ & 3 \\
\hline & \multicolumn{2}{|r}{ Total Pernyataan: } & \\
\hline
\end{tabular}


Tabel 5. Kisi-kisi Angket Tentang Motivasi Belajar

\begin{tabular}{|c|l|c|c|}
\hline No. & \multicolumn{1}{|c|}{ Indikator Item } & $\begin{array}{c}\text { Nomor } \\
\text { Item }\end{array}$ & $\begin{array}{c}\Sigma \\
\text { Item }\end{array}$ \\
\hline 1 & $\begin{array}{l}\text { Timbulnya dorongan siswa dalam mewujudkan } \\
\text { prestasi-prestasi dalam hidupnya }\end{array}$ & $1,2,3$ & 3 \\
\hline 2 & $\begin{array}{l}\text { Dorongan siswa dalam memenuhi kebutuhan } \\
\text { belajar di sekolah }\end{array}$ & $4,5,67,8$ & 5 \\
\hline 3 & $\begin{array}{l}\text { Semangat siswa dalam mewujudkan cita-cita } \\
\text { hidup melalui kegiatan belajar }\end{array}$ & $9,10,11,12$ & 4 \\
\hline 4 & $\begin{array}{l}\text { Semangat siswa dalam memenuhi kebutuhan } \\
\text { hidup melalui kegiatan belajar }\end{array}$ & $13,14,15$ & 3 \\
\hline & \multicolumn{1}{|c|}{ Total Pernyataan: } & & $\mathbf{1 5}$ \\
\hline
\end{tabular}

Pertimbangan pengumpulan data menggunakan angket mengacu pendapat Djumhur (2001: 38) yang intinya menyatakan bahwa: "Teknik angket digunakan untuk mengungkap data penelitian, karena beberapa keuntungan sebagai berikut:

1) Dengan angket dapat diperoleh data yang sesuai dengan keadaan siswa yang sebenarnya, karena diisi oleh responden sendiri mengenai dirinya.

2) Dengan angket diperoleh secara serempak dalam waktu yang bersamaan.

3) Melalui angket ini dalam waktu yang relatif singkat data yang dibutuhkan dalam penelitian dapat serempak dapat diperoleh.

4) Pengaruh antar responden dalam mengisi dapat dihindari, sehingga hasil isi angket menunjukkan kemurnian.

5) Memudahkan responden dalam mengisi angket karena item angket telah dikonstruksi oleh penyusun angket.

Uji validitas butir item angket penelitian ini dengan menggunakan uji validitas logis, yaitu dengan validitas isi (content validity). Penerapan validitas isi (content validity) pada dasarnya untuk menguji validitas butir item pada instrumen penelitian. Penerapan uji validitas tersebut sesuai dengan pendapat Scarvia B. Anderson dan kawan-kawan (dalam Suharsimi Arikunto, 2005: 60), yang menyatakan bahwa: "Validitas isi artinya kejituan dari suatu instrumen penelitian (tes) jikalau ditinjau dari isinya” Lebih lanjut 
Anderson menegaskan bahwa: "Sebenarnya pembahasan tentang validitas ini bukanlah ditekankan pada instrumen (tes) itu sendiri, tetapi lebih ditekankan pada hasil pengetesan atau skornya".

Berdasarkan pendapat di atas, jelas bahwa bukan masalah pertanyaan pada setiap butir item yang menentukan vaiditasnya, tetapi terletak pada skor yang diperoleh melalui instrumen yang digunakan tersebut.

Pendapat di atas diperkuat oleh pendapat Wayan Nurkancana dan P.P.N. Sumartana (dalam Vitalis 2007: 128), yang menyatakan: "Untuk menilai validitas isi itu dilakukan dengan jalan membandingkan materi instrumen yang disediakan dengan analisis rasional yang dilakukan terhadap bahan-bahan yang seharusnya dipergunakan dalam menyusun instrumen tersebut".

Pada intinya Wayan dan Sumartana menegaskan bahwa dengan validitas isi itu dapat diusahakan tercapainya sejak saat penyusunan instrumen dengan cara merinci materi yang akan digunakan sebagai indikator item dalam instrumen tersebut. Jadi jelas sebuah instrumen dikatakan valid bila materi yang dituangkan melalui instrumen tersebut betul-betul merupakan bahan-bahan representatif terhadap tujuan penyusunan instrumen".

Uji reliabilitas item instrumen penelitian pada hakikatnya diperlukan karena hal itu berhubungan dengan masalah taraf kepercayaan atau masalah ketetapan (keajegan). Berkaitan dengan uji reliabilitas ini Scarvia B. Anderson (dalam Suharsimi Arikunto, 2004: 78) menyatakan "Persyaratan validitas dan reliabilitas bagi instrumen itu penting atau diperlukan karena menyokong terbentuknya validitas instrumen. Namun persyaratan validitas instrumen itu justru adalah lebih penting. Pertimbangannya ialah sebuah instrumen mungkin reliabel tetapi belum tentu valid. Sebaliknya, sebuah instrumen (tes) yang valid biasanya reliabel. Jadi, dengan mendasarkan pandangan di atas, maka instrumen yan digunakan dalam penelitian ini telah memenuhi kelayakan sebagai alat ukur. 


\section{Hasil}

\section{Deskripsi Data}

1. Deskripsi Data Skor Angket Perhatian Orang Tua (X)

Berdasarkan penilaian data hasil isian angket tentang perhatian orang tua dengan rentangan skor: 15-60, yang dihitung dengan bantuan program Microsoft Office Excel 2007, Release 12 diperoleh hasil sebagai berikut:

$\mathrm{N}=40$

$$
\mathrm{SD}=4,197
$$

Rata-rata $=52,65$

Skor maksimal $=59$

Mode $=50$

Skor minimal $=44$

Median $=54$

Hasil isian angket tentang perhatian orang tua tersebut di atas akan dilaporkan dalam bentuk grafik, maka data tersebut perlu ditabulasikan ke dalam tabel distribusi frekuensi bergolong. Selanjutnya menghitung range (R) dan lebar kelas (i). Range (R) diperoleh dengan cara mencari selisih antara batas nyata skor maksimal dengan batas nyata skor minimal $(59,5-43,5)=16$. Dengan ditentukan bahwa lebar kelas (i) $=3$, maka perlu menambah 2 point, dengan ketentuan 1 point untuk skor tertinggi dan 1 point untuk skor terendah, sehingga $R=(16+2)$ : $3=(18: 3)=6$.

Distribusi frekuensi bergolong untuk skor angket perhatian orang tua dapat dilihat pada tabel berikut.

Tabel 6. Distribusi Frekuensi Skor Angket Perhatian Orang Tua $\left(\mathrm{X}_{1}\right)$

\begin{tabular}{|c|c|c|}
\hline $\mathbf{I}$ & $\mathbf{X i}$ & $\mathbf{f}$ \\
\hline $58-60$ & 59 & 5 \\
\hline $55-57$ & 56 & 13 \\
\hline $52-54$ & 53 & 7 \\
\hline $49-51$ & 50 & 8 \\
\hline $46-48$ & 47 & 4 \\
\hline $43-45$ & 44 & 3 \\
\hline Total & -- & 40 \\
\hline
\end{tabular}


Bentuk grafik tentang skor perhatian orang tua adalah sebagai berikut:

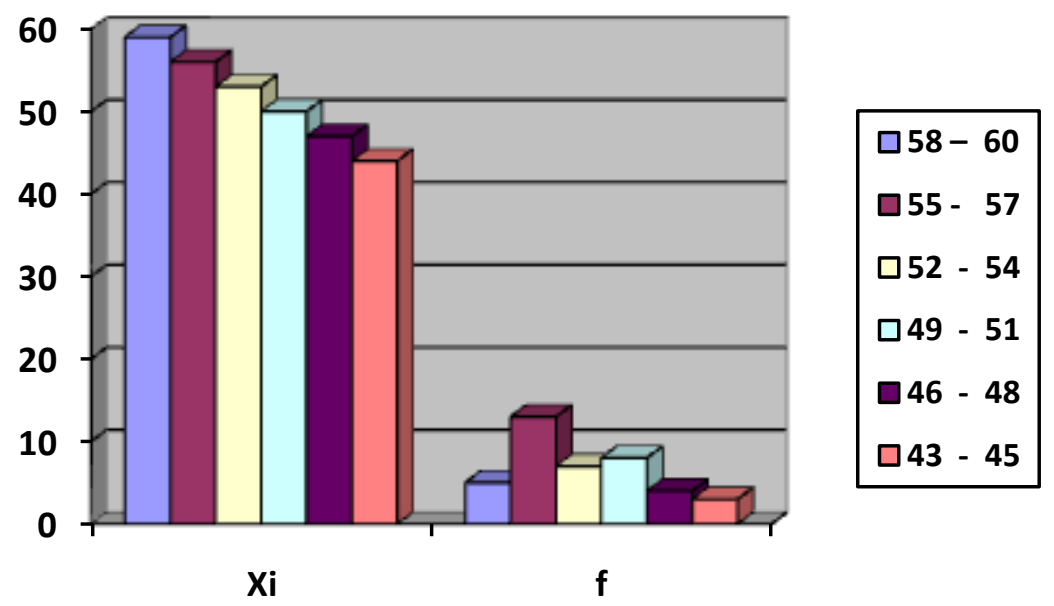

Grafik 1. Skor Perhatian Orang Tua

2. Deskripsi Data Skor Angket Keharomisan Keluarga $\left(\mathrm{X}_{2}\right)$

Berdasarkan penilaian data hasil isian angket keharmonisan keluarga dengan rentangan skor: 15-60, dihitung dengan bantuan program Microsoft Office Excel 2007, Release 12 diperoleh hasil sebagai berikut:

$\mathrm{N}=40$

$\mathrm{SD}=3,897$

Rata-rata $=54,7$

Skor maksimal $=60$

Mode $=56$

Skor minimal $=45$

Median $=56$

Hasil isian angket tentang keharmonisan keluarga tersebut di atas akan dilaporkan dalam bentuk grafik, maka perlu ditabulasikan ke dalam tabel distribusi frekuensi bergolong. Selanjutnya menghitung range (R) dan lebar kelas (i). Range (R) diperoleh dengan cara mencari selisih antara batas nyata skor maksimal dengan batas nyata skor minimal $(59,5-43,5)=16$. Dengan ditentukan bahwa lebar kelas (i) $=3$, maka perlu menambah 2 point, dengan ketentuan 1 point untuk skor tertinggi dan 1 point untuk skor terendah, sehingga $R=(16+2)$ : $3=(18: 3)=6$. 
Distribusi frekuensi bergolong untuk skor angket keharmonisan keluarga dapat dilihat pada tabel berikut.

Tabel 6. Distribusi Frekuensi Skor Angket Keharmonisan Keluarga

\begin{tabular}{|c|c|c|}
\hline $\mathbf{I}$ & $\mathbf{X i}$ & $\mathbf{f}$ \\
\hline $59-61$ & 60 & 3 \\
\hline $56-58$ & 57 & 18 \\
\hline $53-55$ & 54 & 11 \\
\hline $50-52$ & 51 & 3 \\
\hline $47-49$ & 48 & 1 \\
\hline $44-46$ & 45 & 4 \\
\hline Total & -- & 40 \\
\hline
\end{tabular}

Bentuk grafik tentang skor keharmonisan keluarga adalah sebagai berikut:

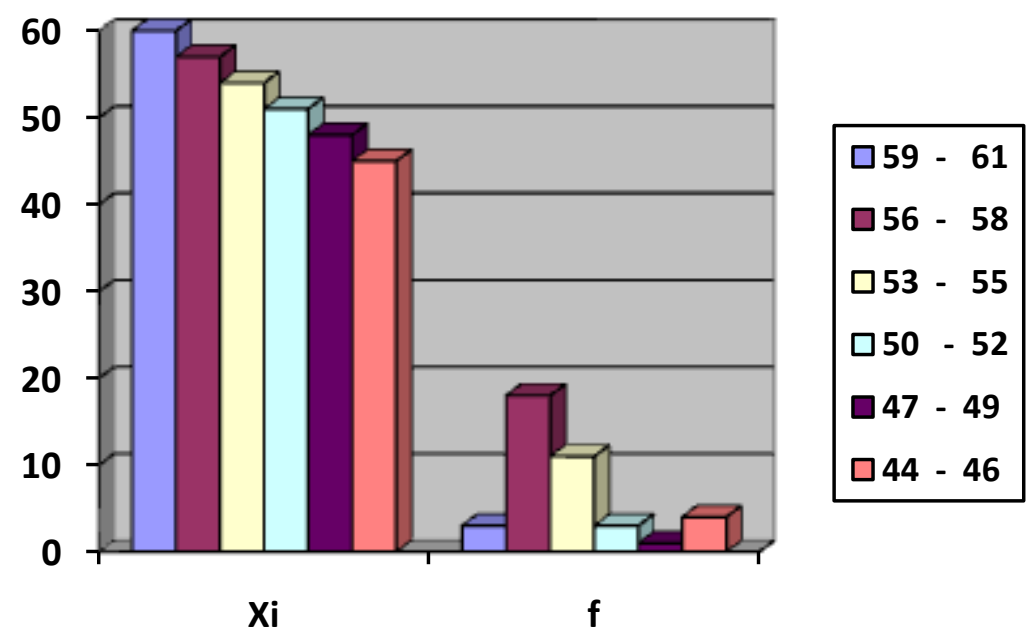

Grafik-2. Skor Keharmonisan Keluarga

3. Deskripsi Data Skor Angket Motivasi Belajar (Y)

Berdasarkan penilaian data hasil isian angket tentang motivasi belajar dengan rentangan skor: 15-60, dihitung dengan bantuan program Microsoft Office Excel 2007, Release 12 diperoleh hasil sebagai berikut:

$\mathrm{N}=40$

Rata-rata $=54,7$

Mode $=56$

Median $=56$
$\mathrm{SD}=3,897$

Skor maksimal $=60$

Skor minimal $=45$ 
Hasil isian angket tentang motivasi belajar di atas akan dilaporkan dalam bentuk grafik, maka perlu ditabulasikan ke dalam tabel distribusi frekuensi bergolong. Selanjutnya menghitung range (R) dan lebar kelas (i). Range (R) diperoleh dengan cara mencari selisih antara batas nyata skor maksimal dengan batas nyata skor minimal $(60,5-44,5)=16$. Dengan ditentukan bahwa lebar kelas (i) $=3$, maka perlu menambah 2 point, dengan ketentuan 1 point untuk skor tertinggi dan 1 point untuk skor terendah, sehingga $R=(16+2): 3=(18: 3)=6$.

Distribusi frekuensi bergolong untuk skor angket perhatian orang tua dapat dilihat pada tabel berikut:

Tabel 6. Distribusi Frekuensi Skor Angket Motivasi Belajar

\begin{tabular}{|c|c|c|}
\hline $\mathbf{I}$ & $\mathbf{X i}$ & $\mathbf{f}$ \\
\hline $59-61$ & 60 & 9 \\
\hline $56-58$ & 57 & 20 \\
\hline $53-55$ & 54 & 6 \\
\hline $50-52$ & 51 & 5 \\
\hline Total & -- & 40 \\
\hline
\end{tabular}

Bentuk grafik tentang skor motivasi belajar adalah sebagai berikut:

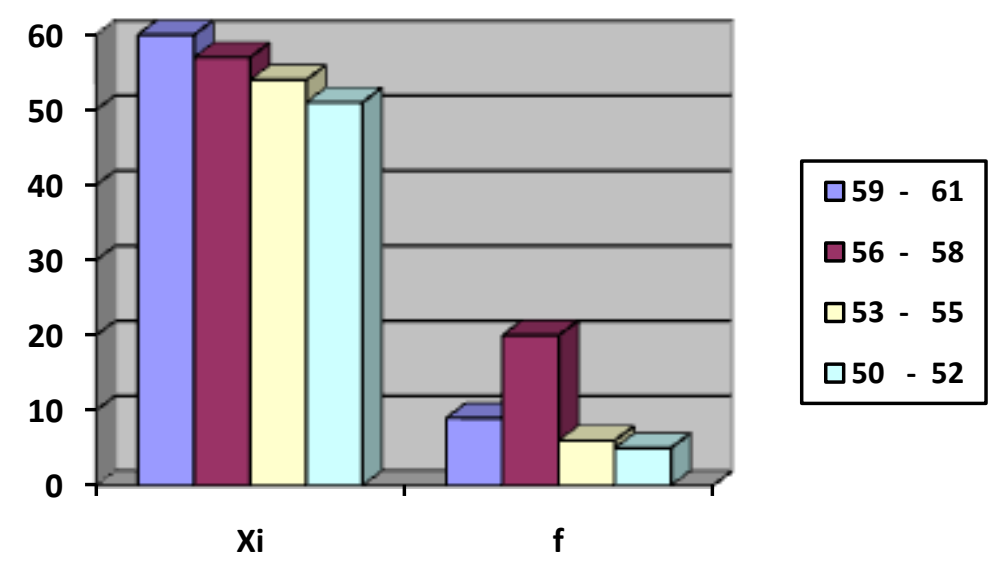

Grafik 3. Motivasi Belajar 


\section{Hasil Analisis Data Penelitian}

1. Analisis Data Pengaruh Perhatian Orang Tua $\left(X_{1}\right)$ Terhadap Motivasi Belajar (Y)

Berdasarkan hasil perhitungan data penelitiaan pada lampiran 7, diperoleh hasil perhitungan bahwa harga $r$-hitung $=0,481$. Langkah selanjutnya harga $r$ hitung $=0,481$ tersebut perlu dikosultasikan dengan harga r-tabel untuk mengetahui signifikan atau tidak signifikan.

Diketahui bahwa harga r-tabel untuk N sebanyak 40, dan derajad bebas adalah $(\mathrm{N}-1)$ atau $39=0,361 / \mathrm{TS}=5 \%)$. Dengan demikian harga $\mathrm{r}$-hitung lebih besar dibandingkan dengan harga t-tabel $(0,481>0,361)$.

2. Analisis Data Pengaruh Kerharmonisan Keluarga $\left(X_{2}\right)$ Terhadap Motivasi Belajar (Y)

Berdasarkan hasil perhitungan data penelitiaan pada lampiran 7, diperoleh hasil perhitungan bahwa harga $r$-hitung $=0,796$. Langkah selanjutnya harga $r$ hitung $=0,796$ tersebut perlu dikosultasikan dengan harga r-tabel untuk mengetahui signifikan atau tidak signifikan.

Diketahui bahwa harga r-tabel untuk $\mathrm{N}$ sebanyak 40, dan derajad bebas adalah $(\mathrm{N}-1)$ atau $39=0,361 / \mathrm{TS}=5 \%)$, sehingga harga $\mathrm{r}$-hitung lebih besar dibandingkan dengan harga t-tabel $(0,796>0,361)$.

3. Analisis Data Pengaruh Perhatian Orang Tua $\left(\mathrm{X}_{1}\right)$ Dan Keharmonisan Keluarga $\left(\mathrm{X}_{2}\right)$ Terhadap Motivasi Belajar (Y)

Berdasarkan hasil perhitungan data penelitiaan pada lampiran 7, diperoleh hasil perhitungan bahwa harga F-reg $=74,512$. Langkah selanjutnya harga F-reg sebesar 74,512 tersebut perlu dikosultasikan dengan harga F-tabel untuk mengetahui signifikan atau tidak signifikan.

Diketahui bahwa harga r-tabel untuk $\mathrm{N}$ sebanyak 40, dan derajad bebas adalah $(\mathrm{N}-\mathrm{m}-1)$ atau atau 2 melawan $37=3,23 / \mathrm{TS}=5 \%)$, sehingga harga r-hitung lebih besar dibanding harga F-tabel $(74,521>3,23)$ 


\section{Kesimpulan dan Saran}

Bertolak dari hasil analisis data penelitian pada bab sebelumnya, maka dapat dikemukakan beberapa simpulan berikut:

1. Ada pengaruh perhatian orang tua terhadap motivasi belajar siswa kelas VIII SMP Negeri 1 Kebonsari Kabupaten Madiun pada tahun pelajaran 2011/2012.

2. Ada pengaruh keharmonisan keluarga terhadap motivasi belajar siswa kelas VIII SMP Negeri 1 Kebonsari Kabupaten Madiun pada tahun pelajaran 2011/2012.

3. Ada pengaruh perhatian orang tua dan keharmonisan keluarga terhadap motivasi belajar siswa kelas VIII SMP Negeri 1 Kebonsari Kabupaten Madiun pada tahun pelajaran 2011/2012.

Bertolak dari simpulan diatas dapat dikemukakan beberapa saran sebagai berikut:

1. Sekolah. Sesuai dengan program pendidikan sekolah, yaitu meningkatkan mutu siswa dan mutu lulusan, maka hasil penelitian ini dapat dimanfaatkan sebagai bahan masukan untuk mengevaluasi program pendidikan yang telah disusun, dan untuk bahan dalam penyusunan program pendidikan akan datang, sehingga bermanfaat bagi perkembangan dan kemajuan siswa di sekolah, khususnya dalam kaitannya dengan keharmonisan keluarga dan dalam mewujudkan motivasi belajar.

2. Guru. Para guru dapat memanfaatkan hasil penelitian ini sebagai dasar dalam memahami pentingnya perhatian orang tua dalam membangun keharmonisan keluarga, sehingga diharapkan dapat memberi dorongan siswa dalam mewujdukan prestsi-prestasi di sekolah.

3. Konselor. Konselor dapat memanfaatkan hasil penelitian ini sebagai bahan masukan yang dapat digunakan sebagai dasar dalam menyusun program layanan bimbingan dan konseling. Lebih lanjut konselor sekolah dapat memanfaatkan hasil penelitian ini sebagai titik tolak dalam membantu siswa yang bermasalah yang bersangkut paut dengan perhatian orang tua 
dan keharmonisan keluarga. Hasil penelitian ini juga dapat dimanfaatkan oleh konselor dalam membantu motivasi belajar siswa di sekolah.

4. Orang Tua. Hasil penelitian ini diharapkan dapat memperbaiki kesadaran orang tua, khususnya yang berhubungan dengan perhatian terhadap anakanak di rumah. Orang tua perlu menyadari bahwa perhatian orang tua di rumah itu tidak dapat dilepaskan dari faktor-faktor yang lain, seperti keharmonisan keluarga, yang pada dasarnya dapat memberi dorongan anak (siswa) dalam mewujudkan prestasi-prestasi di sekolah.

5. Siswa. Siswa dapat memanfaatkan hasil penelitian ini sebagai bahan informasi bagi dirinya, sehingga dapat dimanfaatkan bagi kemandirian belajarnya. Di samping itu dapat bermanfaat sebagai bahan introspeksi bahwa di satu pihak ada kebutuhan untuk diperhatikan orang tua, dan di pihak lain dapat meningkatkan kemandirian belajar siswa, sehingga meningkatkan semangat dalam mewujudkan prestasi-prestasi di sekolah.

6. Bagi Perkembangan Ilmu Pengetahuan

Hasil penelitian ini dapat bermanfaat dan dapat memerikan sumbangsih bagi perkembangan ilmu pengetahuan, pada umumnya, dan dunia pendidikan, tanpa kecuali bagi pengembangan program bimbingan dan konseling.

\section{Daftar Pustaka}

Departemen Penddikan Nasional. 2005. Kamus Besar Bahasa Indonesia. Jakarta: Balai Pustaka

Dimyanti dan Mudjiono. 2002. Belajar dan Pembalajaran. Jakarta: Rineka Cipta Djaali. 2007. Psikologi Pendidikan. Jakarta: Bumi Aksara.

Djumhur. 2001. Bimbingan Dan Konseling Di Perguruan Tinggi. Bandung: PT Remaja Rosdakarya

Gino H.J. dan Kawan-kawan 1994. Belajar dan Pembelajaran I. Departemen Pendidikan dan Kebudayaan Republik Indonesia. Surakarta: Universitas SebelasMaret

Hamzah n B Uno. 2007. Profesi Kependidikan: Problema, Solusi, dan Reformasi Pendidikan di Indonesia. Jakarta: Bumi Aksara

Hamzah n B Uno. 2003. Teori Motivasi \& Pengukurannya: Analisis di Bidang Pendidikan. Jakarta: Bumi Aksara.

Ibadullah Malawi. 2007. Penelitian Pendidikan. Diktat Pembelajaran. Madiun: IKIP PGRI Madiun 
Ishak dan Hendri Tanjung. 2003. Manajemen Motivasi. Jakarta: Grasindo

Made Pidarta. 2007. Perencanaan Pendidikan Partisipatori. Jakarta: Rieneka Cipta

Moeljono Notosoedirjo. 2002. Psikologi Kognitif. Malang: UMM press

Moh Shocib. 2000. Pola Asuh Orang Tua Untuk Membantu Anak Mengembangkan Disiplin Diri. Jakarta : Rineka Cipta

Ngalim Purwanto. 2006. Psikologi Pendidikan. Bandung: PT Remaja Rosdakarya

Slameto. 2003. Belajar dan Faktor-faktor yang Mempengaruhinya. Jakarta: Rineka Cipta

Sofyan H Willis. 2008. Remaja dan Masalahnya. Bandung: Alfabeta

Sugiyono.2011. Metode Penelitian Kuantitatif Kualitatif Dan R\&D. Bandung: Alfabeta

Suharsimi Arikunto.2005. Manajemen Penelitian. Jakarta: Rineka Cipta

Sumadi Suryabrata. 2004. Psikologi Pendidikan. Jakarta: PT Raja Grafindo Persada.Sutrisno Hadi, 2001. Statistik Jilid II . Yogyakarta: Andi Offset

Sutrisno Hadi. 2004. Analisis Regresi. Yogyakarta: Andi Offset

Syaiful Bahri Djamarah. 2002. Psikologi Belajar. Jakarta: Rineka Cipta.

Vitalis, DS. 2002. Perilaku Manusia. Diktat Mata Kuliah Prodi BK Fakultas Ilmu Pendidikan IKIP PGRI Madiun.

Vitalis, DS. 2003. Layanan Bimbingan dan Konseling di Sekolah Menegah Pertama. Panduan Konselor Sekolah Dalam Melaksanakan Tugas Profesionalismenya. Program Studi Bimbingan dan Konsleing Fakultas Ilmu Pendidikan IKIP PGRI Madiun.

Vitalis, DS. 2000. Pengantar Pendidikan. Diktat Mata Kuliah Program Studi Bimbingan dan Konseling, Fakultas Ilmu Pendidikan. Madiun: IKIP PGRI.

Wasty Soemanto. 2003. Psikologi Pendidikan: Landasan Kerja Pemimpin Pendidikan. Jakarta: Rineka Cipta

Wasty Soemanto. 2003. Psikologi Pendidikan: Landasan Kerja Pemimpin Pendidikan. Jakarta: Rineka Cipta.

William J Goode. 2004. Sosiologi Keluarga. Jakarta: Bumi Aksara

Winkel. 2007. Bimbingan dan Konseling Di Institusi Pendidikan. Yogyakarta: Media Abadi

Zakiah Darajat. 2003. Kesehatan Mental. Jakarta: Bumi Aksara 